\title{
Rate of EGFR mutation in patients with pulmonary adenocarcinoma
}

\author{
Waqas Shuaib ${ }^{1}$, Aisha Kousar'2, Nosheen Anwar Bejori' ${ }^{3}$, Asim M Saeed ${ }^{4}$, \\ Emilio A Valdes ${ }^{5}$, Moeed Ahmad', Saleem Khawaja ${ }^{7}$, Tariq I Baloch ${ }^{8}$ \\ ${ }^{I}$ Department of Radiology and Imaging Sciences, Emory University, Atlanta, USA \\ ${ }^{2}$ University Medical and Dental College, Faisalabad, Pakistan \\ ${ }^{3}$ Department of Medicine, Ayub Medical College, Abbottabad, Pakistan \\ ${ }^{4}$ Department of Medicine, Rush University Medical Center, Chicago, USA \\ ${ }^{5}$ Jairo D. Libreros Clinic, Tampa, Florida, USA \\ ${ }^{6}$ Department of Medicine, Queens Hospital Center, Jamaica, New York, USA \\ ${ }^{7}$ Dow University of Health Sciences, Dow Medical College, Karachi, Pakistan \\ ${ }^{8}$ Karachi Institute of Radiotherapy and Nuclear Medicine, Karachi, Pakistan
}

Received September 21, 2014; Revised October 24, 2014; Accepted November 16, 2014; Published Online December 03, 2014

\section{Original Article}

\begin{abstract}
Purpose: Contemporary literature on lung adenocarcinoma has demonstrated a genetic difference of the epidermal growth factor receptor (EGFR) pathway conferring to ethnicity, such as higher frequency of activated EGFR mutations in East Asian population. This information is missing in some developing countries, and we intend to address this gap in the literature. Methods: We examined the rate of EGFR mutations among Pakistani patients with adenocarcinoma of the lung. Fine-needle aspiration samples were gathered from 73 patients. Polymerase chain reaction was performed on extracted DNA for mutational analysis of EGFR exons 19 and 21. Results: EGFR mutations were discovered in 18 of 73 (24.6\%) patients. We did not find any significant difference in EGFR mutation rate with regard to patient's age, sex, smoking history, clinical stage of lung cancer, subtypes of adenocarcinoma, and tumor differentiation. Conclusion: Our investigation shows that the EGFR mutation rate in our patient population with adenocarcinoma of the lung was higher than in African-American, Arabian, and white Caucasian patients, and was lower than the East Asian population.
\end{abstract}

Keywords: Adenocarcinoma; EGFR; Mutation; Lung Cancer

\section{Introduction}

The rate of epidermal growth factor receptor (EGFR) mutation in non-small cell lung cancer is known to vary throughout ethnic groups, with nearly $10 \%$ of patients with non-small cell lung cancer (NSCLC) in the US and 35\% in East Asia have tumor associated EGFR mutations. ${ }^{1-4}$ These mutations occur within EGFR exons 18-21, which encodes a percentage of the EGFR kinase domain. About $90 \%$ of the mutations are exon 19 deletions or exon 21 L858R point mutations. ${ }^{5}$ The influence of ethnicity on the rate of the mutation is poorly understood.

Contemporary literature suggests that EGFR mutations offer survival benefit independent of therapy.6, 7 Literature concentrating on East Asian population indicates that the incidence of classical EGFR mutations is predictive of survival benefit following EGFR tyrosine kinase inhibitor (TKI) therapy. ${ }^{8}$
After a meticulous review of the literature, we did not find any reports of genetic backgrounds of lung cancer in Pakistan. Therefore, we studied the rate of major types of activating mutations in exons 19 and 21 of EGFR in Pakistani patients with adenocarcinoma of the lung.

\section{Methods and Materials}

Seventy-three patients underwent computed tomography (CT)-guided fine-needle aspiration (FNA) biopsy at the Karachi Institute of Radiotherapy and Nuclear Medicine (KIRAN), and Atomic Energy Medical Centre (AEMC) at Jinnah Post Graduate Medical Centre (JPMC) Karachi from 2011 to 2013. The study complies with the institutional review board committee policies. Informed consents were obtained from all participants. 
None of the study participants were exposed to chemotherapy prior to FNA. All pathological diagnoses were conducted by pathologist's blind to the clinical information, and verified by one pathologist in accordance with the WHO classification system.

\section{FNA and DNA samples}

Tumor specimen was obtained using the approved protocols of the IRB through CT-guided FNA biopsies using 23-gauge needles in all participants. Appropriateness for DNA extraction was documented after pathologists confirmed more than $70 \%$ tumor cells in each sample.

FNA samples were instantly stored in tubes containing 99.5\% ethanol at $-80^{\circ} \mathrm{C}$. Genomic DNA was isolated from tissue by removal of ethanol after high-speed centrifugation. A modified procedure using the commercial DNAzol reagent was successfully applied to extract genomic DNA (DNAzol® BD, Molecular Research Center, Cincinnati, USA).

Polymerase chain reaction single-strand conformation polymorphism was utilized to identify mutations in exons 19 and 21 of the EGFR gene. PCR was done by the AmpliTaq Gold PCR Master Mix (Life Technologies, USA). Table 1 illustrates the primers and PCR conditions used. After denaturing PCR products, electrophoresis was done with the GenePhor System and GeneGel Excel 12.5/24 (GE Healthcare, Sweden) at $18^{\circ} \mathrm{C}, 650 \mathrm{~V}$ for 80 minutes. The gels were stained using the DNA Silver Staining Kit (Promega, Madison, WI, USA).

TABLE 1: Association of EGFR gene mutations to clinicopathological features.

\begin{tabular}{|c|c|c|c|c|}
\hline \multirow[b]{2}{*}{ Variable } & \multirow[b]{2}{*}{$\begin{array}{l}\text { Total patients } \\
\qquad(\mathrm{n}=73)\end{array}$} & \multicolumn{3}{|c|}{ EGFR gene mutation status } \\
\hline & & $\begin{array}{c}\text { Mutated } \\
(\mathrm{n}=18)\end{array}$ & $\begin{array}{c}\text { Wild-type } \\
(\mathrm{n}=55)\end{array}$ & P-value \\
\hline Age, median (range) & $58.9(18-84)$ & $61.6(43-79)$ & $56.2(18-84)$ & \\
\hline$<60$ years of age & 47 & $8(17 \%)$ & 39 & 0.12 \\
\hline$\geq 60$ years of age & 26 & $10(38.4 \%)$ & 16 & \\
\hline Gender & & & & 0.39 \\
\hline Male & 53 & $14(26.4 \%)$ & 39 & \\
\hline Female & 20 & $4(20 \%)$ & 16 & \\
\hline Smoking status & & & & 0.95 \\
\hline Never-smoker & 27 & $7(26 \%)$ & 20 & \\
\hline Former-smoker & 12 & $4(33.3 \%)$ & 8 & \\
\hline Current-smoker & 34 & $7(20.5 \%)$ & 27 & \\
\hline Clinical stage & & & & 0.46 \\
\hline Stage I & 10 & $4(40 \%)$ & 6 & \\
\hline Stage II & 20 & $6(30 \%)$ & 14 & \\
\hline Stage III & 18 & $3(16.6 \%)$ & 15 & \\
\hline Stage IV & 25 & $5(20 \%)$ & 20 & \\
\hline Subtypes of adenocarcinoma & & & & 0.63 \\
\hline Bronchio-alveolar & 2 & 0 & 2 & \\
\hline Papillary & 4 & 0 & 4 & \\
\hline Solid & 2 & 0 & 2 & \\
\hline Mixed & 65 & 18 & 47 & \\
\hline Acinar component & & & & 0.54 \\
\hline Present & 41 & $8(19.5 \%)$ & 33 & \\
\hline Absent & 32 & $7(21.8 \%)$ & 25 & \\
\hline Bronchio-alveolar component & & & & 0.87 \\
\hline Present & 14 & $2(14.2 \%)$ & 12 & \\
\hline Absent & 59 & $13(22 \%)$ & 46 & \\
\hline Papillary component & & & & 0.05 \\
\hline Present & 37 & $6(16.2 \%)$ & 31 & \\
\hline Absent & 36 & $12(33.3 \%)$ & 24 & \\
\hline Solid component & & & & 0.23 \\
\hline Present & 16 & $3(18.7 \%)$ & 13 & \\
\hline Absent & 57 & $15(26.3 \%)$ & 42 & \\
\hline Tumor differentiation & & & & 0.23 \\
\hline Well & 9 & $2(22.2 \%)$ & 7 & \\
\hline Moderate & 24 & $5(20.8 \%)$ & 19 & \\
\hline Poor & 40 & $14(35 \%)$ & 26 & \\
\hline
\end{tabular}


TABLE 2: PCR primers and parameters.

\begin{tabular}{clllll}
\hline \hline $\begin{array}{c}\text { EGFR } \\
\text { gene }\end{array}$ & \multicolumn{1}{c}{ Forward (5'-3') } & \multicolumn{1}{c}{ Reverse (5'-3') } & Product size (bp) & Number of cycle & Annealing condition \\
\hline Exon19 & $\begin{array}{l}\text { CGTCTTCCTTCTCT } \\
\text { CTCTGT }\end{array}$ & $\begin{array}{l}\text { CCACACAGCAAA- } \\
\text { GCAGAAAC }\end{array}$ & 148 & 35 & $55^{\circ} \mathrm{C}, 15 \mathrm{~s}$ \\
Exon21 & $\begin{array}{l}\text { AGGGCATGAAC- } \\
\text { TACTTG }\end{array}$ & $\begin{array}{l}\text { CCTCCTTACTTT- } \\
\text { GCCTCCTTC }\end{array}$ & 167 & 35 & $55^{\circ} \mathrm{C}, 15 \mathrm{~s}$ \\
\hline \hline
\end{tabular}

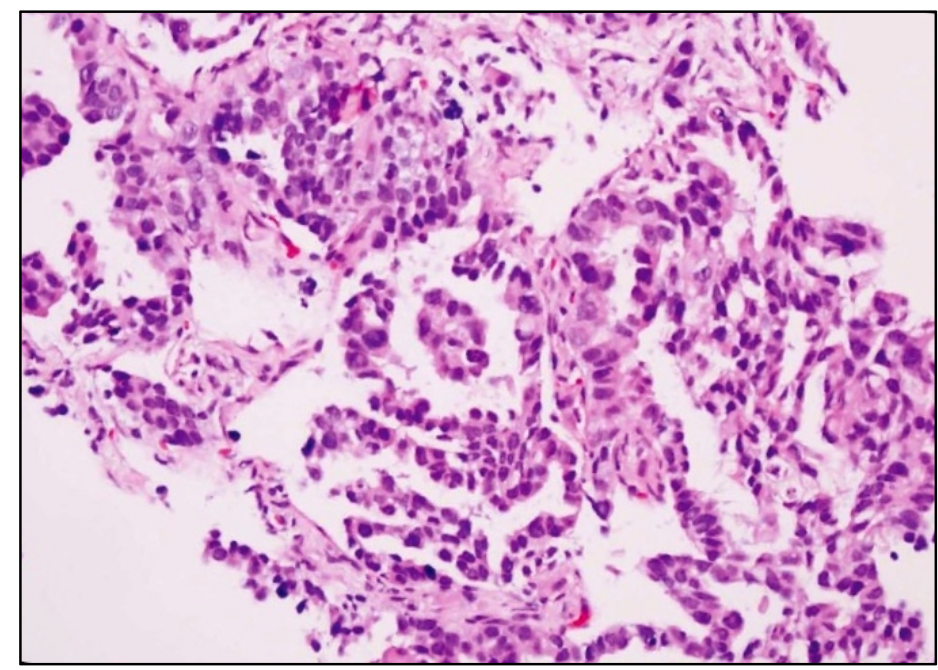

FIG. 1: Adenocarcinoma of the lung.

\section{Statistical analysis}

The incidence of EGFR mutation status along with the corresponding important predictors of incidence of EGFR mutations were additionally identified by logistic regression with a forward-model selection procedure. The factors included in the model selection were age, sex, histology, and stage of the tumor. Continuous measurements between two groups were examined by the $t$ test or Fisher's exact test, whereas, the Mann-Whitney $U$ test determined the differences between the continuous variables. All tests were two-sided. A p-value $<0.05$ was considered statistically significant.

\section{Results}

Of the 73 tumor patients, mutations in exons 19 and 21 of the EGFR gene were detected in $11(15 \%)$ and 7 (9.5\%) tumors. Estimated mutation rate was $24.6 \%$ (18 of 73). Mutation male to female rate was $26.4 \%$ (14 of 53) and 20\% (4 of 20) Table 1. Table 2 reviews the association of EGFR gene mutations to clinicopathological features. A higher incidence of EGFR mutation was appreciated in adenocarcinomas with papillary component (0.05). We did not find any other significant relationship between EGFR mutation rate and patient characteristics.

\section{Discussion}

According to our literature search, our study is the only report available comprising information on EGFR mutations in a Pakistani patient population. Considering that our recruiting site is one of the principal cancer centers in the country, it is likely that our findings closely reflect the overall occurrence of EGFR mutations in the population of Pakistan.

Our study shows that the EGFR mutation rate in Pakistani patients with adenocarcinoma of the lung was higher than the African-American ${ }^{9}$, Arabian ${ }^{10}$, and white Caucasian patients $^{1,2}$, and was lower than in patients in East Asia and other countries of South Asia. ${ }^{11-13}$ This is probably the result of the fundamental differences between cohorts.

It is worth mentioning that a latent tumor stage at diagnosis may have affected the reported ethnic disparity in EGRF mutation rate, since Pakistan has no mandatory national health insurance policy yet, and therefore, Pakistani patients often present at advanced stages of the lung cancer [Figure $1]$.

While our sample size is not sufficient to draw any conclusion, our results however may predict a higher likelihood of important responses to EGFR-TKIs in Pakistani patients with adenocarcinoma of the lung than in African-American, Arabian, and white Caucasian patients. This hypothesis is particularly of interest for patients in Pakistan, where lung cancer cases are diagnosed at advanced stages and surgery is no longer a therapeutic option. Additionally, the conclusions of our study may benefit future prospective clinical trials in- 
crease the number of patients to fully investigate the relationship between the presence of activating EGFR mutation and response to TKIs.

\section{Conclusion}

Epidermal growth factor receptor mutations were found in 18 of 73 (24.6\%) Pakistani patients. Our investigation shows that the EGFR mutation rate in our patient population with adenocarcinoma of the lung was higher than in African-American, Arabian, and white Caucasian patients, and was lower than the East Asian population.

\section{Conflict of interest}

The authors declare that they have no conflicts of interest. The authors alone are responsible for the content and writing of the paper.

\section{References}

1. Pao W, Miller V, Zakowski M, et al. EGF receptor gene mutations are common in lung cancers from "never smokers" and are associated with sensitivity of tumors to gefitinib and erlotinib. Proc Natl Acad Sci US A 2004; 101:13306-11.

2. Paez JG, Jänne PA, Lee JC, et al. EGFR mutations in lung cancer: correlation with clinical response to gefitinib therapy. Science 2004; 304:1497-500.

3. Lynch TJ, Bell DW, Sordella R, et al. Activating mutations in the epidermal growth factor receptor underlying responsiveness of non-small-cell lung cancer to gefitinib. $N$ Engl J Med 2004; 350:2129-39.

4. Calvo E, Baselga J. Ethnic differences in response to epidermal growth factor receptor tyrosine kinase inhibitors. JClin Oncol 2006; 24:2158-63.
5. Ladanyi M, Pao W. Lung adenocarcinoma: guiding EGFR-targeted therapy and beyond. Mod Pathol 2008; 21 Suppl 2:S16-22.

6. Eberhard DA, Johnson BE, Amler LC, et al. Mutations in the epidermal growth factor receptor and in KRAS are predictive and prognostic indicators in patients with non-small-cell lung cancer treated with chemotherapy alone and in combination with erlotinib. J Clin Oncol 2005; 23:5900-9.

7. Bell DW, Lynch TJ, Haserlat SM, et al. Epidermal growth factor receptor mutations and gene amplification in non-small-cell lung cancer: molecular analysis of the IDEAL/INTACT gefitinib trials. $J$ Clin Oncol 2005; 23:8081-92.

8. Mok TS, Wu YL, Thongprasert S, et al. Gefitinib or carboplatin-paclitaxel in pulmonary adenocarcinoma. NEngl J Med 2009; 361:947-57.

9. Leidner RS, Fu P, Clifford B, et al. Genetic abnormalities of the EGFR pathway in African American Patients with non-small-cell lung cancer. JClin Oncol 2009; 27:5620-6.

10. Al-Kuraya K, Siraj AK, Bavi P, et al. High epidermal growth factor receptor amplification rate but low mutation frequency in Middle East lung cancer population. Hum Pathol 2006; 37:453-7.

11. Sahoo R, Harini VV, Babu VC, et al. Screening for EGFR mutations in lung cancer, a report from India. Lung Cancer 2011; 73:316-9.

12. Kosaka T, Yatabe $\mathrm{Y}$, Endoh $\mathrm{H}$, et al. Mutations of the epidermal growth factor receptor gene in lung cancer: biological and clinical implications. Cancer Res 2004; 64:8919-23.

13. Han SW, Kim TY, Hwang PG, et al. Predictive and prognostic impact of epidermal growth factor receptor mutation in non-small-cell lung cancer patients treated with gefitinib. J Clin Oncol 2005; 23:2493-501. 